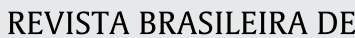

\section{Diversity of sarcosaprophagous Diptera (Calliphoridae, Sarcophagidae) in organic and conventional mango plantations in the Brazilian semi-arid region}

\author{
Rodrigo F.R. Carmo ${ }^{1,2 *}$ (1), Taciano M. Barbosa ${ }^{1,3}$, Aline F. Torris ${ }^{4}$, \\ Mary-Ann S. Bezerra ${ }^{4}$, Simão D. Vasconcelos ${ }^{1}$ \\ ${ }^{1}$ Universidade Federal de Pernambuco (UFPE), Departamento de Zoologia, Grupo de Pesquisa em Insectos de Importância Forense, \\ Recife, PE, Brasil. \\ ${ }^{2}$ Universidade Federal de Pernambuco (UFPE), Departamento de Botânica, Laboratório de Ecologia Aplicada, Recife, PE, Brasil. \\ ${ }^{3}$ Universidade Federal do Rio Grande do Norte (UFRN), Departamento de Microbiologia e Parasitologia, Laboratório de Insetos e \\ Vetores, Natal, RN, Brasil. \\ ${ }^{4}$ Instituto Federal do Sertão Pernambucano, Petrolina, PE, Brasil.
}

\section{A R T I C L E I N F O}

\section{Article history:}

Received 28 October 2020

Accepted 18 February 2021

Available online 22 March 2021

Associate Editor: Rodrigo Kruger

\section{Keywords:}

Caatinga

Agroecosystem

Forensic Entomology

Chrysomya

Oxysarcodexia

\begin{abstract}
A B S T R A C T
Increase on intensive monocultures is an important threat to Caatinga biodiversity decrease. The use of chemical insecticides directly affects insect natural enemies of crops, but also non-target species. We aimed to test whether the diversity of sarcosaprophagous flies would be affected by agricultural management (conventional and organic). Adult dipterans were collected monthly, from July 2015 to January 2016, using a grid composed of 12 suspended traps distant $20 \mathrm{~m}$ from each other, baited with $150 \mathrm{~g}$ of sardine or bovine spleen, in each type of management. We first calculated $\alpha$-diversity by Hill numbers, then evaluated the difference of diversity metrics by ANOVA. We also graphically visualise the species composition distribution by NMDS. We recorded a total of 4,651 specimens of 15 Calliphoridae and Sarcophagidae species. Chrysomya spp. were the dominant species (93.7\% of all blowflies). Sarcophagidae species were sampled in low abundance, but with exclusive presence of some species in each treatment (e.g. B laesoxipha stallengi and Ravinia belforti in organic management). Although there was no difference on sarcosaprophagous fly diversity between treatments, we demonstrate empirically that mango plantations in the Caatinga harbour diverse and abundant assemblages of sarcosaprophagous dipterans, whose richness of species is comparable to other ecosystems such as rainforests and urban areas. Our results expand the known geographical range for forensically relevant species by providing a checklist of sarcosaprophagous dipterans that can thrive in agroecosystems in the Caatinga and, potentially, colonize cadavers disposed in that type of environment.
\end{abstract}

Replacement of native forests by intensive monoculture is one of the major causes for biodiversity loss in the Neotropical Region (Laurance et al., 2014). This is the case of the Caatinga, the largest contiguous area of seasonally dry tropical forest (SDTF) in South America (Silva et al., 2017). The domain is characterized by high temperature, low relative humidity, and low and irregular rainfall $(<700 \mathrm{~mm} / \mathrm{yr})$ (Silva et al., 2017), even so, it has become the largest productive area of exotic crops such as grape and mango in Brazil, particularly in the municipality of Petrolina, State of Pernambuco (IBGE, 2017). However, intensive use of machinery, irrigation and synthetic agrochemicals has raised concerns about changes in the assemblage of native insect species.

While the impact of agricultural practices has been thoroughly studied for insect natural enemies (see Garratt et al., 2011 for a review), their effect on other insect guilds has been largely ignored.

\footnotetext{
* Corresponding author:

E-mail: carmo.rfr@gmail.com (R.F.R. Carmo).
}

Sarcosaprophagous dipteran species, for example, have been more frequently associated with carrion, but several species exhibit a secondary nectarivore behaviour and can act as pollinators of crops, including mangoes (Larson et al., 2001). In addition to their potential role as pollinators (Huda et al., 2015), blowfly (Diptera: Calliphoridae) and flesh fly (Diptera: Sarcophagidae) are the most important taxa in Forensic Entomology, due to their ability to use carcasses as food and as sites for mating and oviposition.

Data on the geographical distribution, seasonal occurrence and response to environmental factors are essential to subsidize protocols for the estimation of the minimum post-mortem interval and provide inferences about the site of death based on entomological evidence. Recent studies confirm the establishment of exotic Calliphoridae species of the genus Chrysomya in the Caatinga (Oliveira and Vasconcelos, 2020), and the ability of Sarcophagidae species (e.g., Blaesoxipha (Gigantotheca) stallengi (Lahille, 1907)) to outdo competitors in the 
colonization of animal baits (Barbosa et al., 2019). The extent to which these ecological features affect their likelihood as cadaver colonizers in rural areas in the semi-arid region is unknown.

Motivated by the lack of empirical studies on sarcosaprophagous insects in an increasingly human-modified Caatinga, we investigated the diversity of Calliphoridae and Sarcophagidae species in a typical agroecosystem in the Caatinga, that is, mango plantations. We aimed to test whether the diversity of sarcosaprophagous flies would be affected by agricultural management (hereafter, conventional and organic). We expected that the diversity of blowflies and flesh flies would be lower in conventional plantations, due to the potential deleterious effect caused by the application of synthetic insecticides on non-target organisms.

The experiments took place in farms of fresh mangoes (Mangifera indica L, cultivar Tommy Atkins) intended to export, inserted in SDTF areas in Petrolina, Brazil (09 $\left.09^{\prime} \mathrm{S}, 40^{\circ} 22^{\prime} \mathrm{W}\right)$. Climate is semiarid (Köppen) with irregular rainfall distribution (average $500 \mathrm{~mm} / \mathrm{year}$ ), concentrated between November and April. Intense solar radiation, low relative humidity, and high temperature (mean $26^{\circ} \mathrm{C}$ ) throughout the year makes it an excellent site for large scale fruit cultivation (Siqueira et al., 2008).

To test our hypothesis, we used two treatments: conventional mangoes management ( $\mathrm{CM}$ - with use of chemical insecticides, based on Espinetoram, Lambda-cialotrina, Indoxacarb and Lufenuron + Profenofós), with 8.0 ha; and organic management (OM - free of synthetic insecticides and fungicides) reaching 5.6 ha. For each treatment, two plantation areas were selected (CM-1: 9 ${ }^{\circ} 21^{\prime} 40.20^{\prime \prime}$ S, 4041'12.75"W; CM-2: 9²1'5.91"S, 40³3'2.00"W; OM-1: 9 20'41.38”'S, 4042'50.01"W; OM-2: 9²2'58.72"S, $40^{\circ} 38^{\prime} 53.06^{\prime \prime} \mathrm{W}$ ), at similar phenological stages (full flowering: more than $50 \%$ of panicle flowers opened), and presented the same microsprinkler irrigation systems. Also, all four plantations are surrounded by Caatinga fragments. The sampling sites were separated from each other from at least $1 \mathrm{~km}$. Agricultural practices in all areas are similar (except for chemical products) and follow the guidelines for Integrated Pest Management (IPM) from the local government institution for research and extension activities (Empresa Brasileira de Pesquisa Agropecuária, Embrapa Semi-Arid).

Adult dipterans were collected using suspended traps $(120 \mathrm{~cm}$ above ground) baited with $150 \mathrm{~g}$ of sardine or bovine spleen, previously exposed in environmental temperature for $24 \mathrm{~h}$ without access of insects (Oliveira and Vasconcelos, 2020). In each experimental area, we established one grid composed of 12 traps distant $20 \mathrm{~m}$ from each other, which were exposed in the field for 48 hours, following previous studies that evidenced the independence of samples (Vasconcelos et al., 2015). We performed monthly sampling expeditions from July 2015 to January 2016, which encompassed both dry (three samplings) and rainy seasons (four samplings), totalling 336 independent samples. We identified the insects using the taxonomical keys of Carvalho and Mello-Patiu (2008) and Vairo et al. (2011).

We first calculated $\alpha$-diversity by Hill numbers. Hill diversity (known as true diversity) is composed by a family of mathematical indices, which differ from each other by exponent " $q$ ". For convenience, we used $\mathrm{q}=0$ (species richness); $\mathrm{q}=1$ (common species, equivalent to Shannon index) and $q=2$ (diversity of dominant species) (Hill, 1973). Then, we estimated the overall rarefaction and extrapolation of species diversity using "iNEXT" package (Chao et al., 2014). Finally, we used one-way ANOVA to evaluate the difference of alpha diversity ( $q=0, q=1$ and $q=2$ ) between the treatments. We used a PERMANOVA analysis associated with Betadisp to evaluate species composition difference within and between treatments. Also, a NMDS was built to demonstrate to graphically visualise the species composition distribution along the treatments.

When all samples were combined, 4,651 specimens of 15 species of Calliphoridae and Sarcophagidae were recorded. Calliphoridae was the most abundant family, with $88.5 \%$ of all specimens and was represented by four genera and six species (Table 1). The combined abundance of Chrysomya albiceps (Wiedmann, 1819), Chrysomya megacephala (Fabricius, 1974) and Chrysomya putoria(Wiedmann, 1819) represented 93.7\% of all blowflies. Three native blowflies species were registered, of which Lucilia eximia (Wiedemann, 1819) was the most abundant (Table 1). Sarcophagidae adults were collected in low abundance (11.5\% of total), represented by six genera and nine species, of which Peckia (Sarcodexia) lambens (Wiedemann, 1830) and Oxysarcodexia thornax (Walker, 1849) were the most abundant (Table 1). However, more than $88.3 \%$ of the specimens in this family were unidentified females at the species level.

After seven months we were able to capture virtually the totality of the diversity of common $(\mathrm{q}=1)$ and dominant species $(\mathrm{q}=2)$ for both, conventional and organic system (Fig. 1a, b, c). All species of Calliphoridae were registered in both management types. The sarcophagids B. stallengi and Ravinia belforti (Prado \& Fonseca, 1932) occurred exclusively in organic management and Microcerella analis (Townsend, 1927) and Oxysarcodexia fringidea (Curran \& Walley, 1934) were restricted to conventional mango plantations. Despite that, there is no species variability within $\left(\mathrm{F}_{1 ; 25}=0.602 ; P=0.443\right)$ and between the treatments (PERMANOVA- $\mathrm{F}_{1 ; 25}=1.745 ; \mathrm{R}^{2}=0.058 ; \mathrm{P}=0.154$ ) (Fig 1d). Overall, the richness $(\mathrm{q}=0)$ of species did not differ between the treatments $\left(\mathrm{F}_{1 ; 292}=0.072 ; P=0.787\right)$. The same pattern was observed to common $\left(\mathrm{q}=1: \mathrm{F}_{1 ; 292}=0.045 ; P=0.832\right)$ and dominant species $\left(\mathrm{q}=2: \mathrm{F}_{1 ; 292}=3.096 ; P=0.079\right.$ ). To Calliphoridae, $C$. albiceps was the dominant species in both management types (Figs. 2a and $2 \mathrm{~b}$ ), but to the Sarcophagidae there was no dominant species (Figs. $2 \mathrm{c}$ and $2 \mathrm{~d}$ ).

We demonstrate empirically that mango plantations in the Caatinga harbour diverse and abundant assemblages of sarcosaprophagous dipterans, whose richness of species is comparable to other ecosystems such as rainforest fragments and urban areas (Vasconcelos et al., 2015). The relatively low species richness found in our study can be explained by the environmental monotonicity of the agro-ecosystem, associated with the urban pressure of the surroundings which promotes, along-time, biological homogenization. The type of management did not affect the species diversity, as all conventional and organic plantations shared the same Calliphoridae and most of Sarcophagidae species (Fig. 1a). Thus, we refuse the initial hypothesis that the organic mango plantations would harbour higher diversity when compared to the conventional system, due to potential negative effects of wide spectrum insecticides, which can negatively affect non-target insect species.

The diversity overlap between the sarcosaprophagous flies in conventional and organic management suggests that IPM guidelines towards rational use of chemical insecticides (Barbosa et al., 2000) are strictly followed by mango producers in Petrolina - if we use those species as indicators of side effects of wide spectrum agrochemicals. However, Sarcophagidae species, such as B. stallengi and $R$. belforti occurred exclusively on organic management, being reasonable to think that such species can be a secondary target on chemical compounds used on conventional plantation. Pollinators are by far the most affected ecological niche among insects in agroecosystems exposed to conventional insecticides (Brittain et al., 2010). Nonetheless, the high frequency of Calliphoridae and Sarcophagidae species along our experiment, denotes the possible use of mangoes orchard as feed resource by these species.

Huda et al. (2015) demonstrated this pollination potential in a field experiment, recording a great visitation rate and high number of pollen grains attached to the body surface of blowflies and flesh flies. In support of this, Rajan and Reddy (2019) demonstrated experimentally that Chrysomya species can be as efficient as Apis species on pollination success and consequently on the mango fruit quality. Despite the low 
Table 1

Richness, abundance and relative frequency of Calliphoridae and Sarcophagidae species sampled in organic and conventional mango plantations in Petrolina.

\begin{tabular}{|c|c|c|c|c|}
\hline \multirow{2}{*}{ Family/Species } & \multicolumn{2}{|c|}{ Conventional } & \multicolumn{2}{|c|}{ Organic } \\
\hline & $\mathbf{N}$ & $\%$ & $\mathbf{N}$ & $\%$ \\
\hline \multicolumn{5}{|c|}{ Calliphoridae } \\
\hline Chrysomya albiceps (Wiedmann, 1819) & 2,019 & 82.31 & 1,450 & 87.09 \\
\hline Chrysomya megacephala (Fabricius, 1794) & 318 & 12.96 & 39 & 2.34 \\
\hline Chrysomya putoria(Wiedmann, 1819) & 20 & 0.82 & 11 & 0.66 \\
\hline $\begin{array}{l}\text { Chloroprocta idioidea (Robineau-Desvoidy, } \\
\text { 1830) }\end{array}$ & 2 & 0.08 & 3 & 0.18 \\
\hline Cochliomyia macellaria (Fabricius, 1775) & 20 & 0.82 & 39 & 2.34 \\
\hline Lucilia eximia (Wiedemann, 1819) & 74 & 3.02 & 123 & 7.39 \\
\hline Total Calliphoridae & 2,453 & 100 & 1,665 & 100 \\
\hline \multicolumn{5}{|c|}{ Sarcophagidae } \\
\hline $\begin{array}{l}\text { Blaesoxipha(Gigantotheca) stallengi(Lahille } \\
\text { 1907) }\end{array}$ & - & - & 1 & 2.50 \\
\hline Microcerella analis (Townsend, 1927) & 2 & 9.09 & - & - \\
\hline Microcerella halli(Engel, 1931) & 3 & 13.64 & 7 & 17.50 \\
\hline $\begin{array}{l}\text { Oxysarcodexia fringidea (Curran \& Walley, } \\
\text { 1934) }\end{array}$ & 2 & 9.09 & - & - \\
\hline Oxysarcodexia thornax (Walker, 1849) & 7 & 31.82 & 11 & 27.50 \\
\hline $\begin{array}{l}\text { Peckia (Sarcodexia) lambens (Wiedemann, } \\
\text { 1830) }\end{array}$ & 6 & 27.27 & 11 & 27.50 \\
\hline Ravinia aureopyga (Hall, 1928) & 1 & 4.55 & 2 & 5.00 \\
\hline Ravinia belforti (Prado \& Fonseca,1932) & - & - & 6 & 15.00 \\
\hline $\begin{array}{l}\text { Tricharaea (Sarcophagula) canuta (Wulp, } \\
\text { 1896) }\end{array}$ & 1 & 4.55 & 2 & 5.00 \\
\hline Sub Total & 22 & 100 & 40 & 100 \\
\hline Sarcophagidae spp. (female) & 256 & & 215 & \\
\hline Total Sarcophagidae & 278 & & 255 & \\
\hline TOTAL & 2,731 & & 1,920 & \\
\hline
\end{tabular}

abundance, Sarcophagidae cannot be neglected as potential pollinators, because some species (e.g. Sarcophaga) have already been registered visiting mango flowers (Sung et al., 2006; Huda et al., 2015). These results reinforce the importance of expanding studies involving sarcosaprophagous flies in different phytophysiognomies.

Numerical dominance of calliphorids over sarcophagids was registered in all sampling months, which was greatly explained by the dominance of $C$. albiceps in both management types, a pattern that was observed for other environments such as rainforest, Caatinga, islands, urban area and sugarcane plantations (Vasconcelos et al., 2015; Carmo and Vasconcelos, 2016). Habitat simplification, as exemplified by the establishment of large monocultures, is prone to favour the replacement of a diverse group of disturbance-sensitive species by a less diverse group of disturbance-adapted species (generalist species). The major subjacent process to land use transformation is the reduction of realized niche, which is less harmful to species with a great niche range, an assumption that is corroborated by the dominance of $C$. species $>90 \%$ of all Calliphoridae specimens).

It is worth noticing that the arrival of Chrysomya species in the Brazilian territory (Guimarães et al., 1978) is contemporary to the instalment of irrigation projects that led up to the development of Petrolina as a major agricultural site in Brazil.

Successful establishment of $C$. albiceps can be also explained by its high biotic potential ( $\mathrm{r}$-strategist), predatory behaviour in immature stage, and pioneering on resource detection (Faria et al., 1999), which explain the non-differences on diversity metrices between treatments (high abundance and dominance). Worryingly, these biological and ecological traits raise concern about the community dynamics in environments under strong anthropogenic impact in a scenario of
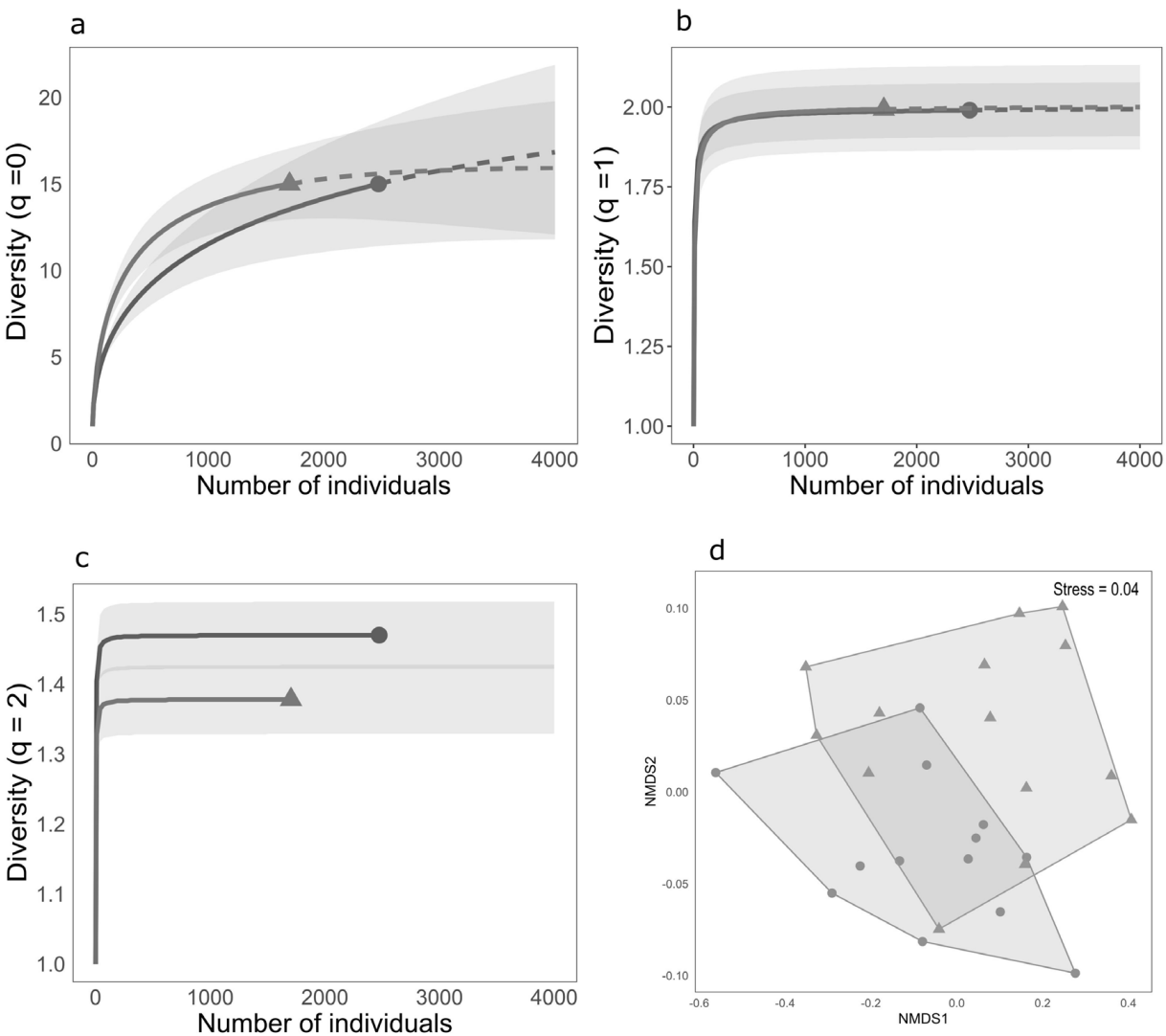

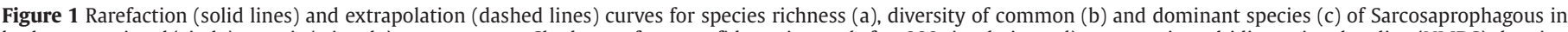

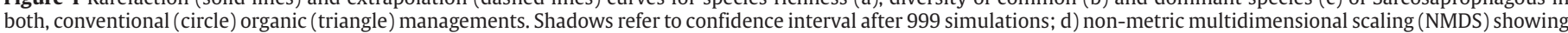
species composition distribution in both conventional (circle) organic (triangle) managements. 


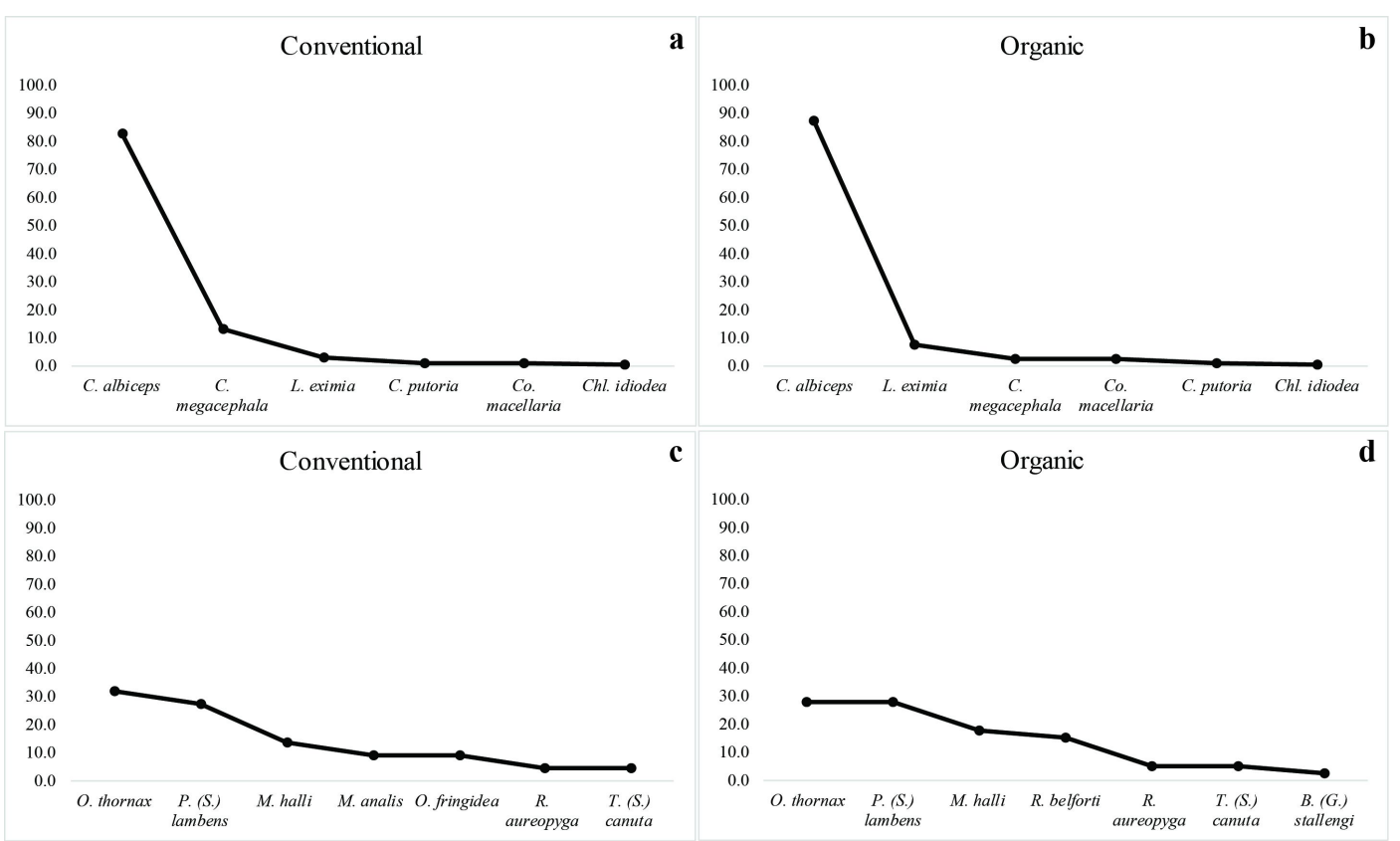

Figure 2 Diptera species dominance ranking by management types. (a and b) Calliphoridae; (c and d) Sarcophagidae.

global changes, because this exotic species may displace or outcompete native species (Faria et al., 2004).

Under a forensic approach, data on the occurrence and dominance of sarcosaprophagous species have tremendous relevance because Calliphoridae and Sarcophagidae are the most frequently used taxa as entomological evidences in criminal investigations. All Calliphoridae species registered here (except $C$. idioidea) and the sarcophagid Microcerella halli(Engel, 1931), $R$. belforti, $P$. (S.) lambens e O. thornax have been reported as colonizers of human cadavers (Oliveira-Costa et al., 2001; Oliveira and Vasconcelos, 2010; Vairo et al., 2017). Blaesoxipha stallengi, on the other hand, is a promising species for bionomical and ecological studies due to its apparent endemism to the Caatinga and unusual reproductive strategies (oviparity) (Barbosa et al., 2019).

Recent reports of Intentional Lethal Violent Crimes (ILVC) indicate changes in the geographical distribution of homicides in Northeastern Brazil - with increasing rates of homicide in the countryside (Pernambuco, 2020). In view of that, the Institute of Scientific Police of Pernambuco have opened working stations in several municipalities inserted into the Caatinga domain, such as Salgueiro, Arcoverde, Ouricuri, Afogados da Ingazeira and, the case of our study, Petrolina. Data on the distribution and seasonal occurrence of necrophagous insect species may help in strengthening scientific procedures associated with the routine of criminal experts. This is interesting in the case of the little-studied L. eximia, a species that has been found colonizing human cadavers in the states of Pernambuco and Paraíba (Guimarães, 2019).

Our results expand the known geographical range for forensically relevant species by providing a checklist of sarcosaprophagous dipterans that can thrive in agroecosystems in the Caatinga and, potentially, colonize cadavers disposed of in that type of environment. This type of entomological evidence is needed to document the likelihood of post-mortem corpse movement and to strengthen database aimed at estimating minimum post-mortem intervals.

\section{Acknowledgments}

We thank Coordenação de Aperfeiçoamento de Pessoal de Nível Superior (CAPES), Conselho Nacional de Desenvolvimento Científico e Tecnológico (CNPq) and Fundação de Amparo à Ciência e Tecnologia do Estado de Pernambuco (FACEPE) for providing PhD scholarship and productivity grants to the authors, Dr. Diego Oliveira and the staff at the Instituto Federal do Sertão and Universidade do Vale do São Francisco for logistical support, Dr. José Siqueira Alves for suggestions, and the owners of the mango farms in which the experiments were performed. This work is the result of integrated cooperation between public universities responsible for ca. $90 \%$ of the Brazilian scientific production, which has been suffering severe lack of investment from the current government.

\section{References}

Barbosa, F. R., Moreira, A. N., Alencar, J. A., Haji, F. N., Medina, V. D., 2000. Metodologia de amostragem e nível de ação para as principais pragas da mangueira no Vale do São Francisco. Embrapa Semi-Árido, Petrolina, PE, 24 pp. (Embrapa Semi- Árido. Circular Técnica, 50).

Barbosa, T. M., Cruz, M. R. P., Pontes, W. J. T., Vasconcelos, S. D., 2019. Aspects of the reproductive behaviour and development of two forensically relevant species, Blaesoxipha (Gigantotheca) stallengi (Lahille, 1907) and Sarcophaga (Liopygia) ruficornis (Fabricius, 1794) (Diptera: sarcophagidae). Rev. Bras. Entomol.63, 124-129. https:// doi.org/10.1016/j.rbe.2019.02.006.

Brittain, C. A., Vighi, M., Bommarco, R., Settele, J., Potts, S. G., 2010. Impacts of a pesticide on pollinator species richness at different spatial scales. Basic Appl. Ecol. 11, 106-115. https://doi.org/10.1016/j. baae.2009.11.007.

Carmo, R. F. R., Vasconcelos, S. D., 2016. Assemblage of necrophagous Diptera in Atlantic insular environments and response to different levels of human presence. Neotrop. Entomol. 45, 471-481.

Carvalho, C. J. B., Mello-Patiu, C. A., 2008. Key to the adults of the most common forensic species of Diptera in South America. Rev. Bras. Entomol. 52, 390-406. https://doi.org/10.1590/S008556262008000300012.

Chao, A., Gotelli, N. J., Hsieh, T. C., Sander, E. L., Ma, K. H., Colwell, R. K., Ellison, A. M., 2014. Rarefaction and extrapolation with Hill 
numbers: a framework for sampling and estimation in species diversity studies. Ecol. Monogr. 84, 45-67.

Faria, L. D. B., Godoy, W. A. C., Reis, S. F., 2004. Larval predation on different instars in blowfly populations. Braz. Arch. Biol. Technol. 47, 887-894. https://doi.org/10.1590/S1516-89132004000600008.

Faria, L. D. B., Orsi, L., Trinca, L. A., Godoy, W. A. C., 1999. Larval predation by Chrysomya albiceps on Cochliomyia macellaria, Chrysomya megacephala and Chrysomya putoria. Entomol. Exp. Appl. 90, 149-155.

Garratt, M. P. D., Wright, D. J., Leather, S. R., 2011. The effects of farming system and fertilisers on pests and natural enemies: a synthesis of current research. Agric. Ecosyst. Environ. 141, 261-270. https:// doi.org/10.1016/j.agee.2011.03.014.

Guimarães, J. H., Prado, A. P., Linhares, A. X., 1978. Tree newly introduced blowfly species in southern Brazil (Diptera, Calliphoridae). Rev. Bras. Entomol. 22, 53-60.

Guimarães, S. E. F., 2019. Entomologia Forense e Estimativa do Intervalo Post-Mortem Mínimo: aplicações no estado da Paraíba. Trabalho de Conclusão de Curso, Curso de Ciências Biológicas, Universidade Estadual da Paraíba, Campina Grande.

Hill, M., 1973. Diversity and evenness: a unifying notation and its consequences. Ecology 54, 427-432.

Huda, A. N., Salmah, M. R., Hassan, A. A., Hamdan, A., Abdul Razak, M. N., 2015. Pollination services of mango flower pollinators. J. Insect Sci. 15, 113. https://doi.org/10.1093/jisesa/iev090.

Instituro Brasileiro de Geografia e Estatística - IBGE, 2017. In São Francisco Valley, Census of Agriculture harvests data from fruits that win the world. Available in https://agenciadenoticias.ibge. gov.br/en/agencia-news/2184-news-agency/news/18695-in-saofrancisco-valley-census-of-agriculture-harvests-data-from-fruitsthat-win-the-world (accessed 15 October 2020).

Larson, B. M. H., Kevan, P. G., Inouye, D. W., 2001. Flies and flowers: taxonomic diversity ofanthophiles and pollinators. Can. Entomol. 133, 439-465.

Laurance, W. F., Sayer, J., Cassman, K. G., 2014. Agricultural expansion and its impacts on tropical nature. Trends Ecol. Evol. 29, 107-116. https://doi.org/10.1016/j.tree.2013.12.001.

Oliveira, D. L., Vasconcelos, S. D., 2020. Do native and invasive blow fly (Diptera: Calliphoridae) species differ in their preferential time of flight? Empirical evidence from a seasonally dry tropical forest. J. Arid Environ. 174, 103985. https://doi.org/10.1016/j.jaridenv.2019.05.013.

Oliveira, T. C., Vasconcelos, S. D., 2010. Insects (Diptera) associated with cadavers at the Institute of Legal Medicine in Pernambuco, Brazil: implications for forensic entomology. Forensic Sci. Int. 198, 97-102. https://doi.org/10.1016/j.forsciint.2010.01.011.

Oliveira-Costa, J., Mello-Patiu, C. A., Lopes, S. M., 2001. Dípteros muscóides associados com cadáveres humanos na cena da morte no estado do Rio de Janeiro, Brasil. Bol. Mus. Nac. 464, 1-6.

Pernambuco, Governo do Estado, 2020. Crimes Violentos Letais Intencionais (CVLI), Secretaria de Defesa Social - PE. Available in https://www.sds.pe.gov.br/estatisticas (accessed 15 October 2020).

Rajan, V. V., Reddy, P. V. R., 2019. A dead heat in pollination race: a comparative evaluation of the efficiency of a fly (Chrysomya megacephala) and a bee (Apis florea) in mango pollination. J. Entomol. Zool. Stud. 7, 1087-1091.

Silva, J. M. C., Leal, I. R., Tabarelli, M., 2017. Caatinga: The largest tropical dry forest region in South America, Springer International Publishing, Cahm.

Siqueira, K. M. M., Kiill, L. H. P., Martins, C. F., Lemos, I. B., Monteiro, S. P., Feitoza, E. A., 2008. Estudo comparativo da polinização de Mangifera indica l. em cultivo convencional e orgânico na região do vale do submédio do São Francisco. Rev. Bras. Frutic. 30, 303-310. https:// doi.org/10.1590/S0100-29452008000200006.

Sung, I. H., Lin, M. Y., Chang, C. H., Cheng, A. S., Chen, W. S., Ho, K. K., 2006. Pollinators and their behaviors on mango flowers in southern Taiwan. Formos. Entomol. 26, 161-170.

Vairo, K. P., Caneparo, M. F. C., Corrêa, R. C., Preti, D., Moura, M. O., 2017. Can Sarcophagidae (Diptera) be the most important entomological evidence at a death scene? Microcerella hallias a forensic indicator. Rev. Bras. Entomol. 61, 275-276. https://doi.org/10.1016/j.rbe.2017.06.004.

Vairo, K. P., Mello-Patiu, C. A., Carvalho, C. J. B., 2011. Pictorial identification key for species of Sarcophagidae (Diptera) of potential forensic importance in southern Brazil. Rev. Bras. Entomol. 55, 333-347. https://doi.org/10.1590/S0085-56262011005000033.

Vasconcelos, S. D., Barbosa, T. M., Oliveira, T. P. B., 2015. Diversity of forensically important dipteran species in different environments in Northeastern Brazil, with notes on the attractiveness of animal baits. Fla. Entomol. 98, 770-775. https://doi.org/10.1653/024.098.0256. 